\title{
PRACHARATH (CIVIL STATE) POLICY FOR ALLEVIATION OF POVERTY IN THAILAND
}

\author{
Sunthan Chayanon \\ Wijittra Srisorn \\ Suan Sunandha Rajabhat University, Bangkok, Thailand
}

Tikhamporn Punluekdej

Southeast Asia University, Bangkok, Thailand

The objective of this research is to study the Pracharath policy or People-State Partnership Model and poverty alleviation in Thailand. The research results show that in order to reduce poverty there must be a solution for all of the interrelated poverty conditions in the structural system. The solutions stemming from individual projects such as a moratorium, village funds, the Bank of the Poor etc. can be used only on a short-term basis. At the same time, socioeconomic structural reformation must be carried out. National development based on foreign investment and trade must be redirected towards human development, employment, resources' development, and domestic market development. There is an obvious need to boost the potential and open up more opportunities for the poor, expand the tax base, develop social protection system for the most needy ones, encourage the initiation of welfare
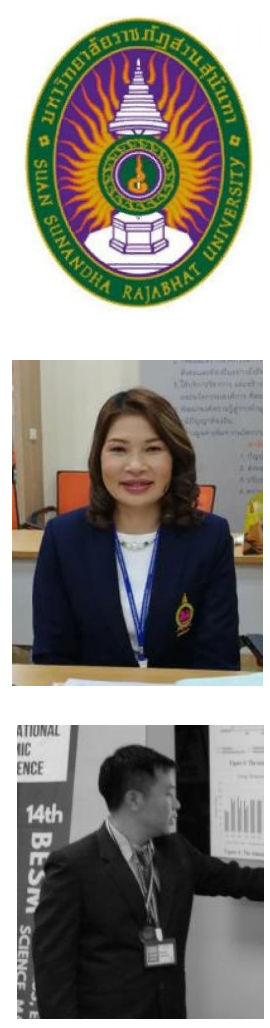

\section{Sunthan Chayanon}

$\mathrm{PhD}$, lecturer in College of Innovations and Management, Suan Sunandha Rajabhat University, Bangkok, Thailand

Science interests: national policy, legislative system, Governance, economy and social regulation

E-mail: sunthan.ch@ssru.ac.th

\section{Wijittra Srisorn}

$\mathrm{PhD}$, Asst. professor in College of Innovations and Management, Suan Sunandha Rajabhat University, Bangkok, Thailand

Science interests: national policy, legislative system, Governance, economy and social regulation

E-mail: wijittra.sr@ssru.ac.th

\section{Tikhamporn Punluekdej}

$\mathrm{PhD}$, Lecturer in Graduate School, South-East Asia University, Bangkok, Thailand Science interests: national policy, legislative system, Governance, economy and social regulation

E-mail: tikhamporn.pu@gmail.com 
funds by communities and decentralization with the responsive budgets on the side of local authorities in order to provide better allocation of the funds concerning resource and environmental management under the local community rights.

Keywords: Pracharath policy; poverty alleviation; sustainable development.

\section{Introduction}

For a long time, Thai government has been using the sufficiency economy philosophy to solve various problems. According to the Government Public Relations Department (2015), sufficiency economy is central to alleviating poverty and reducing economic vulnerability of the poor, according to the Thailand Human Development Report 2007, with the theme of "Sufficiency Economy and Human Development".

This report states, inter alia, that this approach directs attention away from large-scale, capital-intensive projects that often bring more benefits for politicians and contractors rather than for the supposed beneficiaries. Large dams and similar projects are no substitute for the projects that work closer to the ground and involve local communities and numerous households. Poverty alleviation and rural development are inseparable from the environment and natural resources, which are of critical importance for strengthening self-reliance. The care for the environment should also follow the Sufficiency Economy principles. Conservation projects should be low-cost, non-intrusive, and careful in respecting the complex interconnections with the eco-system. As far as possible, they should rely on natural processes, but also borrow technologies where appropriate. In several Thai communities that follow the Sufficiency Economy thinking, this approach to the environment is already an integral part of local planning. The Sufficiency Economy is an alternative approach against the classical development theory that focuses solely on economic growth and industrialization, and is mostly popular among less developed countries (Anantanatorn, 2017).

There are many measures that have been undertaken in order to help farmers and other people with less income in terms of their cost reduction, provision of knowledge, creation of value added, marketing, production factors. And the use of Pracharath policy, or People-State Partnership Model, has been initiated by the government to solve the problems by relying on every possible mechanism in society. Pracharath is composed of the government, private sector, and the people sector. They are collectively helping to solve the problems and trying to find the best solution. This is done through national economic mechanisms that concentrate on eradication of inequality, human quality development, and national competitiveness. The government is expected to develop a policy to smooth differences among people in the country, generate more income and prosperity, and to build economic strength all over the country by means of encouraging the participation of the private and people sectors together with the government in achieving the national vision on stability, prosperity and sustainability.

According to Anan Keitsarnpipop (2017), there are two main operations under Pracharath strategy:

1. The state and the public: the government will act as a facilitator, supporter, and provider of the means and/or channels for participation of the private sector and general 


\section{PRACHARATH (CIVIL STATE) POLICY FOR ALLEVIATION}

people in order to promote a better understanding between the state and the people. There should be no conflict between the people and the government, in the first place.

2. The people and the authorities: there must be cooperation between the people and state authorities for the sake of sustainable development. This can be done through comprehensive Pracharath networks that link and reinforce participation within the society. This is actually the current method of governmental operation. Effective operations must be oriented towards government's budget for the highest benefit of national development, community development, and welfare. Such efforts are expected to increase the quality of life for all people and to prevent social discrimination in the society.

Minh Joo Yi (2019) argued that one of the most recent causes for poverty in Thailand is that economic growth has slowed down, even though it used to be the key driver of poverty reduction in the past. Thailand's average annual economic growth rate was around 7.5\% from 1960 to 1996 and then 5\% in the years following the Asian financial crisis. Such growth generated millions of jobs that contributed to alleviation of a significant share of poverty in the country. However, GDP growth has stalled in the past few years, recording less than $1 \%$ in 2014, and then approximately 3\% in 2015 and 2016. According to Yi, inequality between rural and urban regions also continues to be one of the major causes of poverty in Thailand. Inequality exists among various sectors, the most prominent being education. Thailand's northeastern population is much less educated and more economically disadvantaged as compared to other parts of the country. In 2010, the Office of the Basic Education Commission stated in its assessment report that the number of schools failing to meet the required standards was much higher in the northern and southern provinces than in Thailand's other regions. Because of this worsening disparity, many voices have brought up the need for a drastic reform that would allow for more decentralization of the education system.

Pornpen Vora-Sittha (2012) conducted a research titled "Governance and Poverty Reduction in Thailand" with the objective to find out how Thailand achieves economic growth along with poverty reduction without good governance practice. The relationship among economic growth, poverty indicators and governance indicators are computed by means of Pearson's correlation. The computed results show that poverty reduction in Thailand is achieved through populist policies which are exercised with low quality of governance, not through actual growth. It supports the general belief that the "pro-poor growth" policy alone, without good governance performance, is insufficient for enhancing poverty reduction equally in all regions of Thailand. A strategy for reducing poverty and income inequality for Thailand is not to enhance economic growth but to promote major improvements in governance, especially in part that reflects the perception of three governance composite indicators, namely, Voice and Accountability, Political Stability and Absence of Violence, and the Rule of Law.

The main objectives in cooperation under Pracharath are to reduce inequality, develop human resources, and increase competitiveness. In this respect, the government would like listed companies and private companies to take a lead in helping the country achieve the Pracharat Society which would require much cooperation from private companies to join forces in this state-private-public partnership (Kerdchuay, 2017: 23). Development of such economic grassroot activities is usually focused on rural communities with their rather basic 
agricultural activities. The goal is to create more jobs, generate more income, and overall provide more happiness to the people. There is still a problem with the accessibility of welfare funds for the common people. It is found that rules and regulations concerning access to funds are not flexible enough to facilitate the member participants of such cooperation. Boundaries and guidelines of the regulation over such funds are very much unclear. There are also problems with reporting the performance and the use of funds. Additionally, there is lack of a new generation workers, lack of experience, and finally, lack of appropriate compensation. Finally, personnel in many cases is lacking knowledge on how to use the allocated funds wisely (Meunsai et al., 2017).

\section{Objectives}

The research is aimed to study the Pracharath policy which is also known as the People-State Partnership Model in its direct relation to poverty alleviation in Thailand.

\section{Literature review}

Samchaiy Sresunt (2011) showed variations in the meaning of poverty in Thai society as three overlapping layers: deprivation, which is used to evaluate the poor in a rather straightforward way; development poverty, used for negotiating with the government in the sense of receiving development benefits; and social poverty, used to set social hierarchies. All three meanings have become integrated and today are selectively used in different contexts in everyday life. However, they each share the feature of comparing differing degrees of welfare in their divisions by social classes. This indirectly reflects people's awareness of the poverty gap in Thailand.

Rigg (1998) commented that not only are inequalities in Thailand becoming more acute as economic development proceeds, but that the poor are suffering from a serious fall in their standards of living. This pessimistic vision stands in stark contrast to the "miracle" thesis which is promoted by the World Bank and some economists, as it is reflected in the World Bank's The East Asian Miracle (1993).

Piyanuch Wuttisorn (2014) argued that the issue of poverty and inequality across regions as well as between urban and rural areas in Thailand are the results of imbalanced development. Over the past three decades, Thailand has seen rapid economic growth, as the country pursued industrialization via centralized planning system. During the early development phases, the underlying assumption for such policy was that the benefits of economic development will be "trickled down" to everyone in the country. Accordingly, all the resources - both natural and human resources - were continuously pulled to support industrial production, which is concentrated in a few major cities. With faster industrial growth, labor resources from the agricultural sector migrated to industrial sectors in order to capture the benefits from rapid growth. To support industrialization and business sector growth, infrastructure development had been given priority in the industrialized areas at a cost of rural areas.

Not only that, institutions of higher education and healthcare services have also become primarily concentrated in the industrialized cities. In results, disparities in economic and 


\section{PRACHARATH (CIVIL STATE) POLICY FOR ALLEVIATION}

social development across regions and between rural and urban areas widened, which, in turn, adversely affected overall poverty situation in Thailand.

The Pracharath policy, or People and State Partnership Model, is comprised of 5 main features that are: 1) official units - the governmental units scattered across the country, having necessary knowledge, budget and duties specified by the law; 2) private sector, which includes organizations with sophisticated management styles and flexible operations; 3) the people sector, with the appropriate skills, production skills, and the people's love to their homeland; 4) academic sector which possess the body of knowledge, technologies and research capacities; and finally 5) civil society with its multiple networks.

The most important mission of the government is to build a foundation for Thailand 4.0 in which one of the most important mechanisms is mobilization through the mechanism of Pracharath. Pracharath, or Civil State, is a way to enable people to get benefits from the involvement of the government (Yotkaew, 2016). Most of economic and social problems are always interrelated and tend to have impact on each other. Public problems of any country are always the most complex ones, thus, they always require tighter cooperation from many sides of the society at the same time, among the official units or between the official units and other elements of the society. In the past, people were used to the top-down organization of relations with state administration. But today, we must cooperate in every possible way, which can be top-down, bottom-up, vertically and horizontally. We must consider the holistic picture of the interrelated subsystems that are held together in a matrix. Under the Pracharath concept, the needs of people is always the main focus. The emphasis is placed on participation, official units must encourage the people to think and, at the same time, express their needs and wants freely. The Pracharath strategy also assumes creative cooperation by pulling the advantages of the government, private, academia, civil society, and people sectors for working together. This joint national power is expected to perform good deeds for the benefit of every single citizen of the country, making sure noone is left behind (Mingmaneenakin, 2005).

\section{Development of grassroot economics and the Pracharath}

1. Development of grassroot economics is one of the major objectives of the present government in Thailand. There are already quite many quantitative conclusions on the inequality problems in Thai society resulting from various types of development schemes implemented previously in the country. The major inequality-related problems belong to the following categories: income gap, lack of educational opportunities, employment and stability, living conditions, land use, public health, drugs, security of life and property, overall well-being of families. All these mentioned above problems are always interrelated and complicated. Together they form a chain in which there is no beginning and no end. None of these problems can be solved separately.

However, it is commonly acknowledged that the biggest economic household problems in the country rest with the farmers who are living in the most remote rural areas. Part of these farmers is migrating to cities to find jobs in forms of selling food or being employed as a labor. In general, they have meager incomes, suffer from work instability, have no savings as such and have a tendency to become life-long debtors. This creates a lot of problems later on for themselves and their families. The picture of a peaceful, simple, self-reliant, and dependent on each other community is fading away. In this regard, development of grassroot economy gives some hope. Grassroot economy is quite able to introduce stability, prosperity 
and sustainability in the society at the community level. The objective of Pracharath, in this very context, is to reduce inequality, develop human resources, and increase competitiveness overall. The grassroot economic development committee and the Pracharath are also having another vivid goal that is strengthening the community economy so that people have more income. Supattra Pranee, Boonthai Kaewkhantee, and Chatkaew Hatrawang (2018) argued that communities should be encouraged to become aware on how to combine forces and apply creativity for further human resource development and additional generation of employment and income inside communities themselves.

2. The key strength of community economy means the community can rely economically and sustainably on itself, especially if it manages to facilitate own development for the benefits of the mass. Development of community economy is derived from the strengthened economic factors in all the dimensions, namely:

2.1. The community capital in terms of money. These are savings for production, poverty alleviation project funds, and also village/community fund.

2.2. Natural and environmental resources. This includes fertility of the local land, availability and quality of the local water, natural tourist attractions in the area and so on.

2.3. Cultural and social capital. Various groups and organizations within the community, with all their skills, production capacities and managerial abilities.

2.4. Human capital. These are thinkers and practitioners who are seriously trying to strengthen the community. They possess a certain leadership style and are ready to sacrifice their own interests for the common good. Such people are also the key course of the locally accumulated knowledge. At the same time, they are always ready to learn new things around them in order to develop their neighborhood and community.

3. Operation of the grassroot economic development and the Pracharath committee under the social enterprise concept.

3.1 The operation of the grassroot economic development and the Pracharath

The Ministry of the Interior has been assigned the mission of the grassroot economic development and the Pracharath. The grassroot economic development and Pracharath committee is composed of the Minister of the Interior as a leader of the team, and Mr. Tapana Siriwattanapakdee, the managing director of Thai Beverage Company Limited, as a leader of the private sector. The objective of this structural unit is to create income for the communities for the sake of happiness of all people. There are 3 main issues covered by them: agriculture, transformation, and tourism, organized by the community in the form of Pracharath. There is also a company called Pracharath Rak Sammakkee Company Limited which serves as the key mechanism in these operations. According to MGR Online (2560), the shareholders of this company are major leading corporations of Thailand including those from the governmental sector and the people sector. This company has been organized under the social enterprise concept with the main objective being social concern but not profit-making. The main income comes from consultations provided to the communities. All profits are used for further expansion of services but not for payment of dividends. The management is based on the good governance principles.

3.2 Three activity groups are targets of the operations. The general objective is to create sustainable income based on the concept of grassroot economic development 


\section{PRACHARATH (CIVIL STATE) POLICY FOR ALLEVIATION}

stimulated by the Pracharath committee and the Pracharath Rak Samakkee company. These three groups of activities are as follows:

3.2.1 The agriculture. This is to support the creation of value added for agricultural products of local communities. These products may come from rice fields, or they are aquatic products or livestock. They can be related to a certain geographic identity in terms of, for example, community history, way of life of a community, genotype, dominant flavor, health, safety and cleanness, biological safety, special care for the highest benefit for the consumers, and friendly environment. These products have a story to tell and in such a way they can differentiate from other products in terms of quality and special features. Therefore, the related efforts are taken in order to increase this value added. On the top of that, the agricultural product quality systems such as Participatory Guarantee System (PGS) as developed by the International Federation of Organic Agriculture Movements (IFOAM), Good Agriculture Practice (GAP), and Q Standard are taken into use together with the special attention paid by farmers to see through that their products really have the highest quality.

3.2.2 The transformation. This element is supposed to support products' transformation from raw materials that are available in a community in various types such as agriculture, livestock, and fishery. The transformation is expected to take place in order to increase the commercial value of the products. This can be done through better preservation process and/or adjustment and adaptation of flavors to suit the consumer taste. Production of handicraft commodities, for example, is based on local wisdom of the villagers. This can come in the form of ornaments, house decoration objects, apparels, and souvenirs. These products may be modified so that they look different from the objects used in real daily lives of villagers. The effort here is on making sure that the local products can be relatively easy accepted by outsiders. Little by little, with the distinctive quality and features, these local products can generate stable inflow of income for the community. The good example in this regard is OTOP - the one-tambon-one-product policy. There are many successful products produced by small and medium enterprises that are developed from local products through the processes of production quality control, packaging, and appropriate marketing strategy.

3.2.3 Tourism by the community. This element is aimed to encourage the community to benefit from tourism business organized locally. There can be natural tourist attractions available in a community or there can be tourist attractions developed by the community itself stemming from its culture, traditions, local wisdom, and occupation and the way of life that is specific for this very region. There is always a combination of the interrelated tourist activities since there are tourist attractions or activities, tourist guides, food and beverage stores, accommodation options, and other appropriate supporting services, like bicycles or boats for rent, original community products, souvenirs, spa and so on. There must also be a tourist management system which would coordinate tourist programs, prices, have an information counter, guarantee overall safety and first aid service etc. Indirectly, this would be the sign of the community's readiness to drawing the attention of prospective tourists. 


\section{The sustainable development concept and theory}

The contemporary concept of sustainable development has been developed in the frameworks of forestry management and careful consideration towards the environment in the late 20th century (Wikipedia, 2016). The United Nations held its first meeting on the environment at Stockholm, Sweden, back in 1972. Later on in 1983, the World Commission on Environment and Development was developed to study the balance between environment and development. The report called "Our Common Future" was distributed around the world asking the world population to restrain from the extravagant life in order to secure a more friendly development for the environment. This report was presented at "The Earth Summit" held in Rio de Janeiro, Brazil back in 1992. After this meeting, the paper entitled "Brundtland Report" has provided the definition of sustainable development as "development in response to the needs of the existing generation but not depriving the ability to fulfill the needs of the future generations" (Seangchai, 2545).

There are many important dimensions in a wide phenomenon of sustainable development. Each dimension can be further subdivided into smaller issues, such as environmental issues, economic issues, political issues, and cultural issues, to mention just a few. When sustainable development is related immediately to local people, it is usually called "social sustainability" (Borja \& Castells, 1997). Regional development can take different turns in this regard. Some cities can develop by focusing on their sustainability. Some cannot do that since they have a lot of problems with budget deficit, for example, or they experience the inability to respond to the sophisticated needs of the local people. Many cities use their preservative and revival policies to maintain domestic sustainability instead of an increment in budget to deal with environmental problems or destruction of local natural resources. Regional sustainable development is necessary for the survival of society and it should be considered as a collective action of the whole wide world at the same time.

Special efforts should be taken for provision of knowledge, promotion of economy that creates more jobs, establishment of the mechanisms to promote civil participation and democracy, adjustment of social structures, and fighting against social discrimination (Grumm, 1975). Moreover, sustainable development is not just about the environment and the related technical issues, it also concerns the behavior that can be amended by providing right education and by letting people participate in the matters that concern them. Sustainable development is also directly interrelated with social integration. If the level of unemployment is still quite high and there are a lot of discriminated people, sustainability cannot be reached.

The related social policies must be directed towards the provision of education, employment among local residents, birth control, as well as the increasing quality of public healthcare. At present, there are a lot of local areas in the world facing many related obstacles and, as a result, sustainable development is hardly even an objective for them, especially when they need to concentrate primarily on the issues of employment, poverty and even basic hygiene. These are the key problems against sustainability.

For example, poverty is a major cause of environmental deterioration and poor hygiene since people do not have enough income to satisfy their even most basic needs. At the same time, unemployment makes sustainably development impossible as such. Unemployment and poverty also have negative effect on the ability to get proper housing conditions. This, in turn, means less opportunities to receive services at their proper level and overall quality of life would be very much low. Social sustainability requires participation on all sides of life, 


\section{PRACHARATH (CIVIL STATE) POLICY FOR ALLEVIATION}

starting with guaranteed shelter and finishing with free land use and availability of other employment opportunities which provide the foundation for further improvement of life quality (Rossi \& Freeman, 1993).

Economic sustainability is a wide concept and it is directly related to the concept of life quality. In the globalization age, production processes, sales and advanced means of communication are important factors drawing foreign investments into localities and predetermining the need for highly skilled labor. Good social environment is also an important factor in supporting better quality of human resources which includes their growing effectiveness and positive attitude to work overall.

Since local areas are the ones that create problems, they should be also the ones to solve these problems by creating social environment that facilitates economic sustainability. Local areas often tend to have quite high potential to solve the problems and thus lead the territory to sustainability and they are also the key to local people's survival (Vedung, 2008).

\section{Methodology}

This is a qualitative research. Documentary data found in official papers, research studies, textbooks, as well as electronic media have been analyzed. The focus group research with the representatives of the committee and members of the Pracharath projects has been conducted to collect the needed information. Participative and non-participative observations have been also organized. Structured interviews have been done with the committee and members of the Pracharath projects. All of the collected data has been analyzed by means of content analysis. Further data presentation is descriptive in style.

\section{Results}

Poverty problems are caused by economic and political structures, often stemming from the capitalism concept itself. Lack of education and/or income is not the whole story. Possible solutions to poverty problems must be found taking into account the specificity of the local poverty conditions. This would be called the integration approach. Solutions provided separately, such as a moratorium, village funds, and the Bank for the Poor would have much lower efficiency. The following efforts must be undertaken under this integration approach:

1. Reformation of the general socioeconomic structure, starting with land reform, agricultural reform, fiscal and monetary policies changes, revised taxation (especially in part of property tax), education reform, public healthcare improvement, mass communication development, political reforms, and social transformations. The key purpose here is to reconsider the ownership forms and control over production factors so that to make them more just, democratic, and effective at the same time. Development of new cooperatives, community organizations and public companies must be organized under the conditions of free and fair competition.

2. Expansion of the taxation base by means of providing new financial opportunities for those who previously did not have access to financial services and resources. State and local budgets must be reconsidered in favor of public health and education for the poor people. Stronger support for poverty alleviation projects and social capital initiatives should be provided through closer cooperation with local people. Establishment of communities' 
educational networks should include transferring of knowledge, sharing local wisdom, exchanging local technologies and joint research. Introduction of new learning opportunities must lead to collective actions in various fields of activities, all being aimed at sufficient way of life and closer collaboration with the government.

3. Establishment of a social protection system for the least fortunate people. Local communities themselves are expected to initiate the establishment of such welfare funds. There can be also a special, additional unemployment fund; social security system should be expanded in such a way to cover the informal sector as well. Local businesses that demonstrate to be having positive impact on the savings within the community should be supported and encouraged in their development by all means possible. Stable employment overall is the key performance factor in the strongest communities. Employment is the key to justice, effectiveness, and equality.

4. Improvements in management system. This concerns political decentralization and allocation of funds on the local level. Local people should have easies access to the available fund when it comes to management of local resources and environment as the latter is supposed to be the integral right of the local community. Issuance of license documents to poor farmers and the use of wilderness and deserted areas should become more popular. Moreover, there should be a special plan for the use of local lands in agriculture and industries. Preservation areas, lands under community forests and development of water reservoirs should be specified in great deal of detail. Allocation of lands and other natural resources must be fair and based on the careful revision, taking into account the specificity of the local areas and the ongoing changes in natural resources and the environmental situation overall.

Poverty can be viewed in its many dimensions. As a care-taker, the government is expected to provide all its citizens with decent living conditions but the overall economic development cannot actually guarantee that every citizen will automatically have higher standards of life. Therefore, it is necessary to look into details of societal problems and find out what are the real causes beind these problems. Generally speaking, the poverty problem in Thailand has been continuously decreasing. However, as this is a traditional agricultural society, the poor people usually come from the households with less social and cultural opportunities. The poor can also belong to a certain ethnic group which traditionally has lower socioeconomic status or have a certain social background that is just considered inferior in the society overall. On the other hand, there are also poor people because they were born disabled, or suffered from a severe disaster, got divorced and/or have no one to look after etc. This type of relative poverty in a traditional agricultural society is considered to be not a serious problem. Some community have less inequality in their socioeconomic situation; there are also communities that state they have no poverty problem as such, simply because they do not perceive their current socioeconomic situation as a problem.

\section{Conclusions and Discussion}

Eradicating poverty in all its forms remains one of the greatest challenges the humanity is facing today. While the number of people living under extreme poverty dropped by more than half between 1990 and 2015 - from 1.9 bln to $836 \mathrm{mln}$ - too many are still struggling for the most basic human needs (UNDP in Thailand, 2018). With the recognition of the multidimensional nature of poverty, the government has already taken a holistic approach to 


\section{PRACHARATH (CIVIL STATE) POLICY FOR ALLEVIATION}

poverty eradication. Every government, directly or indirectly, has declared a war against poverty and made poverty eradication an issue on the national agenda. Many governments are also trying to fight three key problems in parallel and their interrelation - poverty, drugs and corruption.

Consequently, Thai government has also announced three policies to deal with this range of interrelated problems.

First, it has a policy directly on poverty eradication. This policy is implemented at all levels, namely individual, community, and national. At the individual level, the government emphasizes particularly on expenses' reduction, income generation, and opportunity provision. At the community level, community participation and learning process are encouraged so as to mobilize people to solve local problems and satisfy local needs together. Moreover, financial assistance is made available to ensure the poor have more access to the funds. At the national level, attempts are being made to reform, restructure, and better manage lands, natural resources, and environment in the context of being supportive of the poor at the same time.

The second component is the policy on developing life quality for the people by means of securing housing for the poorest.

The third one is the policy of natural resources and environmental management. Its key aim concerns balancing between utilization and conservation of natural resources and environment, with a special emphasis on collaboration of the government with the private sector.

Regarding government-level operations on poverty, it takes an integrated approach to mobilize all relevant governmental agencies and their available resources to fight poverty at all levels. Nonetheless, the Area-Function-Participation (A-F-P) Approach is emphasized when implementing poverty eradication activities at the grassroot level. A village or a community or a tambol (sub-district in Thailand) would be a development base for which all government agencies concerned integrate their services to help the poor by improving their living conditions while all other fellow men are also encouraged to take part in these poverty eradication activities.

This is in line with the research conducted by Pimpanga Pangnarain (2015) under the title "A Research Project to Alleviate Poverty and Strengthen Immunity via the Sufficiency Economy" in which it was found that: 1) poor people are present in the country in moderate numbers; 2) the government must find ways to reduce production costs in agriculture and provide extra occupation for the poor people, and also to find speakers to train poor people on how to produce products for the use in their own households; 3) poverty reduction can take the form of a reduction in personal and/or family expenses, an increase in income through extra occupation, and an opportunity for the poor people to get access to governmental resources and decision-making on them; and 4) poverty reduction based on the Sufficiency Economy principles usually take the form of bio-extracting projects, production of household utensils etc.

Although Pracharath is a form of civil government with the participation of all sectors in the process of policy implementation but, in real-life practice, it is impossible to conclude that Pracharath, or Civil State, is totally different from the populist policies, so widely spread in the past. This is in congruence with the work undertaken by Sompong Kesanuch, Thongkam Duangkhunpet, Apiwatchai Phuttajorn, Pakdee Phosing and Sanya Kenaphoom (2017) called 'Analysis of State Policy of 'Populism' to 'Civil State:' Similarities and 
Differences from Thai Government's Decision" in which it was discovered that both of these policies are determined by political institutions with the same type of management power. There is a difference in the objectives of the policy though: populist policies were set up with the main reason of meeting the needs of most people at the grassroot level in order to get political popularity, while Pracharath is determined to wipe out populist policies and is implemented to solve domestic economic problems as well as to create and maintain a sustainable economic and social development model.

\section{Suggestions}

Warr (2004) argued that sustained reduction of poverty in Thailand has occurred over the period of several decades. This reduction in absolute poverty has occurred in spite of an increase in inequality over the same period. The rate of poverty reduction has been strongly related to the rate of GDP growth but the increase in inequality has not. The long-term growth of Thai economy has been associated with a gradual opening to international trade and investments. The prospects for reducing poverty by raising minimum wages are believed to be not that effective in this regard.

Using the community-based approach, Thai government has attempted to provide extra enabling facilities and necessary resources to support the poor people in both rural and urban communities to work together to solve personal and community problems and meet the most urgent needs. Moreover, people are encouraged by both the government and the civic sector to act on such matters by themselves through community participation and learning process. Learning by doing, people, rich and poor alike, will eventually gain more knowledge and skills, and thus gain confidence in management of their lives as well as of communities.

Thus, this paper puts forward the following suggestions:

1. National development policy on investments and foreign trade should be redirected towards human development, employment, natural resources and domestic market development. Foreign investments and trade are often limited and are based on necessities. A policy shift from the growth of products and services onto the development of life quality and environment seems to be appropriate.

2. Reduction of poverty as a policy should be implemented on a continuous basis. There must be always a follow-up assessment system based on integration among related units, associate members, and various networks in order to develop village and/or community funds through participative and self-reliant development towards strengths, stability and sustainability.

3. In what concerns natural resources management, there should be an additional encouragement for the local people to manage natural resources better, and adjust the local laws in part of dealing with natural resources.

4. There should be training programs on skills' development and improvement, legal knowledge, financial knowledge, technological knowledge, and business knowledge. These efforts can be taken through cooperation among public, private and people sectors in order to support, promote, and provide assistance to the operations of village funds and urban community as well. 


\section{PRACHARATH (CIVIL STATE) POLICY FOR ALLEVIATION}

\section{References:}

Anantanatorn, A. (2017). The Philosophy of Sufficiency Economy in Thailand: An Innovative Approach for Development of Poor Countries. Journal of Politics, Administration and Law. 7: 297-323.

Borja, J. \& Castells, M. (1997). Local and Global: Management of Cities in the Information Age. London: Earthscan Publications.

Grumm, J. G. (1975). The Analysis of Policy Impact. In: Greenstein, F. I. \& Polsby, N. W. (Eds.). Handbook of Political Science. 6. Politics and Policy Making. Massachusetts: Addison-Wesley Publishing.

Keitsarnpipop, A. (2017). Roy Riang Muang Thai. Bangkok: Legislative Institutional Repository of Thailand.

Kerdchuay, S. (2017). Consolidating Listed Companies, Enhancing Thai Society. IOD Boardroom, 54 (5): 20-24.

Meunsai, S., Klaaidej, P. \& Srisaard, W. (2017). The Accessibility of Supporting Fund on Welfare Organization. Social Welfare in Nakhon Ratchasima Province. Research and Development Journal on Anthropological and Social Science, Valaya Alongkorn Rajabhat University. 12,2.

MGR (2017). Pracharath builds a better life for Thai people. Retrieved from: https://mgronline.com/qol/detail/960000009391 on February 2, 2562.

Mingmaneenakin, W. (2005). The Macroeconomics. Bangkok: Thammasat University Press.

Minh Joo Yi (2019). Five Facts About Poverty in Thailand, 10 Facts About Education in Thailand, Why Is Thailand Poor? Retrieved from: https://borgenproject.org/causes-of-poverty-inthailand/

Pangnarain, P. (2015). A Research Project to Alleviate Poverty and Strengthen Immunity via the Sufficiency Economy. Dhonburi Rajabhat University Journal. 9 (2): 52-60.

Pranee, S., Kaewkhantee, B. \& Hatrawang, C. (2018). The Comparative Study of Factors Influencing the Decision to Purchase OTOP products, Ranong Province. Journal of Technical Education Development, 30 (106): 93-104.

Rigg, J. (1998). Tracking the poor: the making of wealth and poverty in Thailand (1982-1994). International Journal of Social Economics, 25, 6/7/8: 1128-1141.

Rossi, Peter H. \& Howard E. (1993). Evaluation: A Systematic Approach. London: Sage Publications.

Seangchai, S. (2002). The Environment: Ideology, Politics and Sustainable Development. Bangkok: National Institute for Development Administration (NIDA).

Sresunt, S. (2011). The myth of poverty in Thai society: the archaeology of meaning. South East Asia Research. 19-3: 421-456.

The Government Public Relations Department (2015). Sufficiency Economy to Help Reduce Poverty. Bangkok: The Government Public Relations Department.

UNDP in Thailand (2018). Sustainable Development Goals. Bangkok: United Nations Development Programme.

Vedung, E. (2008). Public Policy and Program Evaluation. New Jersey: Transaction Publishers.

Vora-Sittha, P. (2012). Governance and Poverty Reduction in Thailand. Modern Economy. 3: 487497.

Warr, P. (2004). Globalization, Growth, and Poverty Reduction in Thailand. ASEAN Economic Bulletin, 21 (1): 1-18.

Wuttisorn, P. (2014). Rural-Urban Poverty and Inequality in Thailand. Paper Presented at the International Policy Workshop on Rural-Urban Poverty Linkage.

Yotkaew, P. (2016). Civil State: Buddhist Oriented to Marketing. Journal of MCU Peace Studies. 4: $27-38$ 
Paper submitted

Paper accepted for publishing Paper published online
06 May 2019

23 June 2019

08 August 2019 